Article

\title{
Prevalence, Risk Factors and Genotypes of Giardia duodenalis in Sheltered Dogs in Tuscany (Central Italy)
}

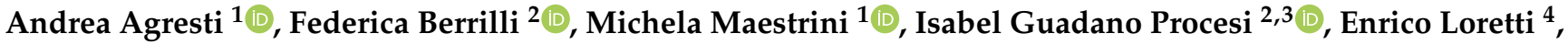 \\ Niccolò Vonci ${ }^{5}$ (D) and Stefania Perrucci ${ }^{1, *(D)}$ \\ 1 Department of Veterinary Sciences, University of Pisa, 56124 Pisa, Italy; a.agresti@studenti.unipi.it (A.A.); \\ michela.maestrini@phd.unipi.it (M.M.) \\ 2 Department of Clinical Sciences and Translational Medicine, University of Rome "Tor Vergata", 00133 Rome, \\ Italy; berrilli@uniroma2.it (F.B.); Isabel.Guadano.Procesi@uniroma2.it (I.G.P.) \\ 3 Department of Biology, Ph.D. Program in Evolutionary Biology and Ecology, University of Rome "Tor \\ Vergata", 00133 Rome, Italy \\ 4 Unità Funzionale Aziendale Igiene Urbana, Az. USL Centro Toscana, 50127 Firenze, Italy; \\ enrico.loretti@uslcentro.toscana.it \\ 5 Unità Funzionale Igiene Epidemiologia e Sanità Pubblica, Azienda USL Toscana Centro, \\ 50032 Borgo San Lorenzo, Italy; niccolo.vonci@uslcentro.toscana.it \\ * Correspondence: stefania.perrucci@unipi.it; Tel.: +39-050-2216949
}

check for

updates

Citation: Agresti, A.; Berrilli, F.; Maestrini, M.; Guadano Procesi, I.; Loretti, E.; Vonci, N.; Perrucci, S. Prevalence, Risk Factors and Genotypes of Giardia duodenalis in Sheltered Dogs in Tuscany (Central Italy). Pathogens 2022, 11, 12. https:/ / doi.org/10.3390/pathogens11010012

Academic Editor: Natasha

N. Gaudreault

Received: 26 November 2021

Accepted: 21 December 2021

Published: 23 December 2021

Publisher's Note: MDPI stays neutral with regard to jurisdictional claims in published maps and institutional affiliations.

Copyright: (C) 2021 by the authors. Licensee MDPI, Basel, Switzerland. This article is an open access article distributed under the terms and conditions of the Creative Commons Attribution (CC BY) license (https:// creativecommons.org/licenses/by/ $4.0 /)$.

\begin{abstract}
In sheltered dogs, the prevalence of Giardia duodenalis is frequently high and may include potential zoonotic genotypes. The prevalence, genotypes and potential risk factors of G. duodenalis were assessed in 168 dogs from four kennels (Pistoia, Prato, Florence, Valdarno) in Tuscany, central Italy and compared with data from previous Italian studies. The prevalence of other intestinal parasites was also investigated. Individual dog faecal samples collected from each kennel were examined by parasitological techniques and a rapid immunoassay for the detection of G. duodenalis and Cryptosporidium faecal antigens. On Giardia-positive samples, molecular analysis was performed for genotype identification. Overall, $69 \mathrm{dogs}$ scored positive for G. duodenalis (41\%), but significant differences $(p \leq 0.05)$ were found among the four kennels and sampling seasons. The potentially zoonotic assemblages A and B and the canine-specific assemblage C (Pistoia: A-AII, B, C; Prato: A-AII, B; Florence: A-AII; Valdarno: A and C) were identified. Toxocara canis (8.9\%), Trichuris vulpis (3.6\%), hookworms (1.19\%) and Cryptosporidium sp. (0.6\%) were also identified. The high prevalence of $G$. duodenalis and the identification of potentially zoonotic genotypes in all examined kennels underline the need to improve routine parasite monitoring and control measures and to provide insights into the zoonotic potential of G. duodenalis.
\end{abstract}

Keywords: Giardia duodenalis; intestinal parasites; kennels; prevalence; genotypes; risk factors; central Italy

\section{Introduction}

Giardia duodenalis (syn. Giardia intestinalis, Giardia lamblia) is a worldwide-distributed intestinal flagellated protozoan that can infect domestic and wild animals, including dogs and humans [1,2]. The life cycle of G. duodenalis is direct and involves only two stages, the trophozoite and the cyst. Hosts may become infected via ingestion of infectious $G$. duodenalis cysts in contaminated food or water sources, or directly (cysts and trophozoites) via the faecal-oral route [1].

The localisation site of G. duodenalis is the small intestine, mainly the duodenum and jejunum, and the infection may be asymptomatic or may cause intestinal disease of different severity $[3,4]$.

Molecular studies have shown that G. duodenalis includes eight distinct genotypes, also called assemblages, identified with the alphabetic letters from A to H [1]. Assemblages $\mathrm{C}$ and $\mathrm{D}$ are canine specific. Assemblages $\mathrm{A}$ and $\mathrm{B}$ are most frequently found in humans, 
but they can also infect other animals and are considered potentially zoonotic [5-8]. Assemblages A and B have been further divided into sub-assemblages (A-I to A-III and B-III, B-IV), some of which are more common in humans and others in animals [2,5]. Sub-assemblage A-I has been reported in humans and animals, while A-II is considered human specific but has also been identified in dog faecal samples $[9,10]$. Assemblage A-III has been detected exclusively in animals [5,11]. Although no definitive transmission between animals and humans has been documented, data from cross-sectional surveillance studies and assessments during giardiasis epidemics greatly support this possibility [9,12-15].

The prevalence of $G$. duodenalis infection in dogs varies depending on the population and area under examination, the diagnostic method used and the health status of the animals examined [16,17]. Young dogs, mainly puppies under 6 months of age, and some dog populations, such as stray or community-living animals, and breeding and sheltered dogs, show a higher risk of infection $[4,8,16]$. Furthermore, in conditions of high animal density and in highly contaminated environments, such as in shelters, repeated infections can be observed due to poor protection conferred by the immune system, continuous exposure to the parasite and continuous introduction of new animals $[5,16,18]$.

In previous European studies [6,7,19,20], including most studies performed in Italy [21-26], the prevalence of $G$. duodenalis ranged between $20 \%$ and $57 \%$ in dogs.

In kennel dogs, canine host-specific assemblages $C$ and $D$ have been more frequently reported in European countries, such as the UK and Spain, but these animals can also be infected by the zoonotic assemblages A and B $[7,19]$. These data agree with those from sheltered dogs in Italy [21-25], in which assemblages $C$ and $D$ were found to be prevalent, but assemblage A was also observed. However, assemblage B was identified only in a single kennelled dog in northern Italy [26].

Feng and Xiao [2] found that an increase in G. duodenalis zoonotic assemblages is observed in dogs when human-animal contacts are high. In fact, it has been highlighted that two transmission cycles may be present in urban environments with the transmission of canine-specific assemblages between dogs and potential transmission of zoonotic assemblages, mainly assemblage A, between dogs and humans $[1,2,5,13,27,28]$. The transmission of dog-specific genotypes is thought to be favoured by intense contact among dogs living in large communities, competing with the transmission of other genotypes, especially in crowded kennels with poor hygiene [1,2,5]. However, zoonotic $G$. duodenalis assemblages (A and B) and sub-assemblages (AII, BIII and BIV) have been increasingly documented among kennel dogs in Europe in recent years [3,6,19,25].

The objectives of this study were to evaluate the prevalence and potential contributing factors, such as age, shelter of provenance and seasonality, of G. duodenalis in kennel dogs in Tuscany (central Italy); to identify the genotypes of G. duodenalis isolates; and to compare obtained data with those reported in dogs from Italy.

\section{Results}

\subsection{Parasitological and Immunological Analysis}

Overall, 69 out of 168 examined dogs scored positive for G. duodenalis, with a prevalence of $41.07 \%$. The highest prevalence of G. duodenalis was found among puppies younger than 6 months of age (8/11 dogs, prevalence $72.73 \%)$, followed by the 6-12 month (18/28 dogs, prevalence $64.29 \%), 1-8$ year (27/78 dogs, prevalence $34.62 \%$ ) and $>8$ year $(16 / 51$ dogs, prevalence $31.37 \%)$ age groups. However, these differences were found to be significant $(p<0.05)$ only at univariate statistical analysis (Table 1$)$.

Among the examined kennels, in the kennel in Pistoia (25/33 dogs, prevalence $75.76 \%$ ) the prevalence of G. duodenalis was significantly higher $(p<0.05)$ compared with that found in other shelters, while the lowest prevalence was found in the Florence kennel (13.64\%, $3 / 22$ dogs) (Table 1). The prevalence of G. duodenalis found in the kennels of Valdarno and Prato was 33.85\% (22/65 dogs) and 39.58\% (19/48 dogs), respectively. 
Table 1. Results of multivariate logistic regression analysis regarding the prevalence of Giardia duodenalis in different kennels, seasons and age groups.

\begin{tabular}{cccc}
\hline & Odds Ratio & $p$ & Confidence Interval 95\% \\
\hline Pistoia & 1 & Kennels \\
Firenze & 0.057 & $0.000^{*}$ & $0.012-0.266$ \\
Prato & 0.215 & $0.004^{*}$ & $0.075-0.620$ \\
Valdarno & 0.167 & $0.000^{*}$ & $0.006-0.456$ \\
& 1 & Age & \\
0-6 months & 0.716 & 0.702 & $0.129-3.965$ \\
6-12 months & 0.267 & 0.098 & $0.056-1.273$ \\
1-8 years & 0.246 & 0.086 & $0.050-1.222$ \\
$>$ 8 years & 1 & Season \\
Autumn & 0.338 & $0.021 *$ & $0.134-0.851$ \\
Winter & 0.511 & 0.137 & $0.211-1.237$ \\
Spring & 0.785 & 0.718 & $0.211-2.921$ \\
Summer &
\end{tabular}

* Statistically significant values; the significance level was set at $p<0.05$.

The number of dogs positive for $G$. duodenalis was high in all seasons, namely 27/50 dogs in autumn (54\%), 16/50 dogs in winter (32\%), 19/52 dogs in spring (36.54\%) and 7/9 dogs $(77.78 \%)$ in summer. However, using multivariate analysis, the prevalence in winter was observed to be significantly lower $(p<0.05)$ than in other seasons (Table 1 ).

Concerning the other identified intestinal parasites, a total of 23 dogs were found positive for intestinal nematodes (23/168 dogs, 13.69\%). More specifically, Toxocara canis was identified in 15 dogs (15/168, prevalence 13.69\%), Trichuris vulpis in 6 dogs (6/168, $3.57 \%$ ) and hookworms (Ancylostoma caninum/Uncinaria stenocephala) in 2 dogs (2/168, $1.19 \%$ ). T. canis was present in all examined kennels. A single dog (>8 years) from the Florence kennel was found positive for Cryptosporidium sp. $(1 / 168,0.6 \%)$.

Multiple parasite infections were detected in 14 dogs found to be infected by 2 or 3 parasite species $(14 / 168,8.33 \%)$. Specifically, 13 dogs were found to be infected by $G$. duodenalis and T. canis/hookworms/T. vulpis (13/168,73.74\%), while a single dog scored positive for G. duodenalis, Cryptosporidium sp. and T. canis (1/168, 0.6\%).

\subsection{Molecular Analysis}

Molecular analysis was performed on 25 out of the 69 Giardia-positive isolates, and positivity was confirmed in all of them. Sequence analysis of the SSU-rRNA gene fragment allowed assignment of the isolates to the potentially zoonotic assemblages $\mathrm{A}$ and $\mathrm{B}$ and to the dog-specific assemblage C (Table 2). A total of 16 isolates were assigned to assemblage $\mathrm{A}$, 5 of which were identified as sub-assemblage AII ( 3 at $\beta$-giardin locus and 2 at tpi locus); 6 to assemblage B; and 2 to assemblage $C$. Based on the double peaks at the diagnostic positions, a single sample was found concurrently positive for assemblages A and assemblage B (Table 2). G. duodenalis genotypes identified in each kennel were A-AII, B and C in the shelter of Pistoia; A-AII and B in the shelter of Prato; A-AII in the shelter of Florence; and A and $C$ in the shelter of Valdarno.

Table 2 shows data regarding G. duodenalis genotypes identified in this study and previously reported in dogs in different areas of Italy. 
Table 2. Genotypes of Giardia duodenalis in dogs from Italy in previous studies and in the present study.

\begin{tabular}{|c|c|c|c|c|c|c|}
\hline Region & Dog Population & N. Dogs & Assemblage (\%) & Locus & $\begin{array}{l}\text { Time Tested } \\
\text { (Year) }\end{array}$ & References \\
\hline Lombardy region & & & $\mathrm{A}(28.6 \%)$ & & & \\
\hline $\begin{array}{l}\text { (Northwestern Italy) } \\
\text { and Veneto region }\end{array}$ & $\begin{array}{c}\text { Kennel and privately } \\
\text { owned dogs }\end{array}$ & 21 & $\begin{array}{c}\mathrm{C}(4.7 \%) \\
\mathrm{D}(61.9 \%)\end{array}$ & $\beta$-giardin & 2003 & $\begin{array}{l}\text { Lalle et al., } 2005 \\
\text { [29] }\end{array}$ \\
\hline (North-eastern Italy) & & & $\mathrm{A}+\mathrm{D}(4.7 \%)$ & & & \\
\hline $\begin{array}{l}\text { Abruzzo region } \\
\text { (Central Italy) }\end{array}$ & $\begin{array}{c}\text { Kennel and privately } \\
\text { owned dogs }\end{array}$ & 240 & $\begin{array}{c}\text { C }(10 \% \text {, only in } \\
\text { privately owned } \\
\text { dogs }) \\
\text { D-D1 }(83.3 \%) \\
\text { A-AI }(6.7 \% \text { only in } \\
\text { privately owned } \\
\text { dogs })\end{array}$ & $\begin{array}{l}\text { SSU-rRNA+ } \\
\beta \text {-giardin }\end{array}$ & 2003-2005 & $\begin{array}{l}\text { Paoletti et al., } \\
2008 \text { [22] }\end{array}$ \\
\hline $\begin{array}{c}\text { Latium } \\
\text { (Central Italy) }\end{array}$ & Kennel dogs & 127 & $\begin{array}{l}\mathrm{A}(30.7) \\
\mathrm{C}(53.8) \\
\mathrm{D}(15.3)\end{array}$ & SSU-rRNA & 2005-2006 & $\begin{array}{l}\text { Scaramozzino } \\
\text { et al., } 2009 \text { [23] }\end{array}$ \\
\hline $\begin{array}{c}\text { Apulia } \\
\text { (Southern Italy) }\end{array}$ & $\begin{array}{c}\text { Free-roaming dogs in } \\
\text { a Rom camp }\end{array}$ & 14 & AI (100\%) & $\beta$-giardin & unspecified & $\begin{array}{l}\text { Marangi et al., } \\
2010 \text { [13] }\end{array}$ \\
\hline $\begin{array}{c}\text { Tuscany } \\
\text { (Central Italy) }\end{array}$ & Privately owned dogs & 239 & $\begin{array}{l}\text { C }(77.8 \%) \\
\text { A }(22.2 \%)\end{array}$ & $S S U-r R N A+g d h$ & 2008-2010 & $\begin{array}{c}\text { Riggio et al., } 2013 \\
{[30]}\end{array}$ \\
\hline $\begin{array}{c}\text { Sardinia } \\
\text { (Southern Italy) }\end{array}$ & $\begin{array}{l}\text { Privately owned dogs } \\
\text { and kennel dogs }\end{array}$ & 655 & $\begin{array}{c}\text { C }(36.1 \%) \\
\text { D }(49 \%) \\
\text { AII }(4.2 \%)\end{array}$ & $\begin{array}{c}\text { SSU-rRNA + } \\
\beta \text {-giardin }\end{array}$ & 2007-2010 & $\begin{array}{c}\text { Pipia et al., } 2014 \\
\text { [31] }\end{array}$ \\
\hline $\begin{array}{l}\text { Lombardy region } \\
\text { (Northwestern Italy) }\end{array}$ & $\begin{array}{l}\text { Privately owned } \\
\text { dogs }\end{array}$ & 253 & $\begin{array}{l}\mathrm{C}(54.5 \%) \\
\mathrm{D}(45.5 \%)\end{array}$ & SSU- $r R N A$ & 2010-2011 & $\begin{array}{l}\text { Zanzani et al., } \\
2014 \text { [32] }\end{array}$ \\
\hline $\begin{array}{c}\text { Veneto } \\
\text { and Friuli-Venezia } \\
\text { Giulia regions } \\
\text { (Northeastern Italy) }\end{array}$ & Shelter dogs & 318 & $\begin{array}{c}\mathrm{C}(46.23 \%, 49 / 106) \\
\text { D }(27.36,29 / 106) \\
\text { B1 }(0.94 \%, 1 / 106)\end{array}$ & SSU-rRNA & 2008-2012 & $\begin{array}{l}\text { Simonato et al., } \\
2015 \text { [26] }\end{array}$ \\
\hline Central Italy & $\begin{array}{l}\text { Privately owned and } \\
\text { kennel dogs }\end{array}$ & 502 & $\begin{array}{c}\mathrm{C}(75 \%, 15 / 20) \\
\mathrm{D}(10 \%, 2 / 20) \\
\mathrm{C}+\mathrm{D}(15 \%, 3 / 20)\end{array}$ & SSU-rRNA & 2011-2013 & $\begin{array}{l}\text { Paoletti et al., } \\
2015 \text { [24] }\end{array}$ \\
\hline $\begin{array}{l}\text { Latium region } \\
\text { (Central Italy) }\end{array}$ & Stray dogs & 262 & $\begin{array}{l}\mathrm{C}(24 \%) \\
\mathrm{D}(76 \%)\end{array}$ & $S S U-r R N A$ & 2014-2015 & $\begin{array}{c}\text { De Liberato et al., } \\
2018 \text { [33] }\end{array}$ \\
\hline $\begin{array}{c}\text { Tuscany and Latium } \\
\text { regions } \\
\text { (Central Italy) }\end{array}$ & Shelter dogs & 639 & $\begin{array}{l}\text { A }(33 \%) \\
C(67 \%)\end{array}$ & SSU-rRNA & 2011-2014 & $\begin{array}{c}\text { Sauda et al., } 2018 \\
\text { [25] }\end{array}$ \\
\hline $\begin{array}{l}\text { Tuscany region } \\
\text { (Central Italy) }\end{array}$ & Privately owned dogs & 47 & $\begin{array}{l}\mathrm{C}(83.3 \%, 5 / 6) \\
\mathrm{D}(16.7 \%, 1 / 6)\end{array}$ & SSU-rRNA & 2016-2017 & $\begin{array}{c}\text { Perrucci et al., } \\
2020 \text { [34] }\end{array}$ \\
\hline $\begin{array}{l}\text { Campania region } \\
\text { (Southern Italy) }\end{array}$ & Privately owned dogs & 24 & $\mathrm{D}(100 \%, 6 / 6)$ & $\beta$-giardin & 2018-2019 & $\begin{array}{c}\text { Ciuca et al., } 2021 \\
\text { [35] }\end{array}$ \\
\hline $\begin{array}{l}\text { Tuscany region } \\
\text { (Central Italy) }\end{array}$ & Shelter dogs & 168 & $\begin{array}{c}\mathrm{C}(8 \%, 2 / 25) \\
\text { A }[64 \%, 16 / 25 \text { of } \\
\text { which } 20 \%, 5 / 25 \\
\text { AII)] } \\
\text { B }(24 \%, 6 / 25) \\
\text { A+B }(4 \%, 1 / 25)\end{array}$ & $\begin{array}{c}\text { SSU-rRNA } \\
+\beta \text {-giardin }+ \text { tpi }\end{array}$ & 2018-2019 & Present study \\
\hline
\end{tabular}

\section{Discussion}

The prevalence of canine $G$. duodenalis infection is highly variable, greatly dependent on the immune status, age and lifestyle of animals, and on the geographical area examined [17]. The mean prevalence of G. duodenalis in dogs appears to be about $15 \%$ [17], but it can be higher than $45 \%$ [11]. Higher prevalence rates in kennel or shelter dogs compared to household or owned dogs are widely evidenced worldwide [36,37], with prevalence ranging from $20 \%$ to $59 \%$ in Europe $[6,7,19,20]$, as in almost all the studies performed in Italy $[21-26,38]$. The overall prevalence of $G$. duodenalis found in the dogs included in this study $(41.07 \%)$ was extremely high, and it was high among all kennels examined, therefore confirming the high prevalence previously reported in shelter dogs in the European territory.

It has been observed in many studies that dogs younger than one year of age are more likely to be positive for $G$. duodenalis $[16,17,22,30,32,38,39]$. This observation was confirmed in this study, which highlighted a significantly higher prevalence in puppies 
under 6 months of age $(72.73 \%)$ and in subjects of the 6-12 month age group $(64.29 \%)$ compared to older age groups. However, the statistical significance of this factor emerged only at the univariate analysis due to the small number of young subjects examined in this study.

Concerning the season, multivariate logistic regression analysis evidenced that the risk of $G$. duodenalis infection was lower in winter than in other seasons. This result disagrees with those found in some previous studies carried out in the same region (Tuscany) and in other geographical areas, in which both privately owned and sheltered dogs were considered [40-42]. Seasonal differences in the management of the kennels here examined, a higher parasite spread in some seasons compared to other seasons and, lastly, seasonal environmental conditions that may favour the possibility for infected dogs to have more contact with other animals may represent some potential factors explaining this result.

Among the examined shelters, the prevalence found in the Pistoia kennel in this study was significantly higher (about $75.8 \%$ ) compared to that observed in the other kennels previously examined in the European territory. Moreover, the prevalence of G. duodenalis in the Pistoia kennel was characterised by high rates in all seasons of the year and in all animal age groups. These findings may suggest that a number of factors may contribute to the high prevalence of G. duodenalis in this kennel. Overcrowding is considered a favourable factor for the spread of this protozoan parasite $[3,8,16]$. Effective sanitisation and control measures may also be more difficult to perform in these conditions. Therefore, a reduction in animal density and improvement in hygienic and control measures are advised in this kennel. Nevertheless, hygiene and effective control measures should be improved in all examined kennels, as in all of them, G. duodenalis prevalence was high. Moreover, in this study, other parasites, including potentially zoonotic species, such as T. canis, Cryptosporidium sp. and hookworms [24,43], were often found to be associated with G. duodenalis.

Among effective measures, diagnostic procedures and treatment of new entry animals, periodic parasite monitoring, cleaning, disinfection of the premises and dog walking areas with effective antiparasitic products, and washing of dogs after treatment for G. duodenalis have been recommended [16,44].

The confirmation of the molecular positivity for G. duodenalis and the high prevalence of potentially zoonotic assemblages identified in shelters here examined underline the importance of this parasite as an additional potential public health risk. In fact, the zoonotic assemblage A was identified in all examined kennels and the human-specific sub-assemblage AII in three of them. The zoonotic assemblage B was also present in two kennels, but sequences from assemblage $B$ isolates were characterised by larger genetic variability and by the presence of heterogeneous positions, which made assignment to specific genotypes difficult, as evidenced in other studies [45]. Assemblage $C$ was identified only in two kennels. Furthermore, multiple genotypes ( 2 or 3 ) were found concurrently present in each kennel.

In previous studies carried out in Italy in different dog populations, the canine-specific assemblages $C$ and $D$ were found to be highly prevalent $[25,26,30,46]$. However, the potentially zoonotic assemblage A was additionally identified $[23,25,30]$, while the zoonotic assemblage B has been rarely detected in dogs in Italy [26]. Therefore, the high prevalence of potentially zoonotic genotypes and the frequent finding of assemblage B in this study do not agree with previous data on dogs in Italy. However, assemblage B was found to be prevalent in sheltered dogs in a recent study in Spain [19].

From the detailed examination of the genotypes identified in the different dog populations examined in the various studies performed in Italy, including the present study, a high variability in the frequency of canine and potentially zoonotic genotypes can be observed. More specifically, it emerges that in some studies, potentially zoonotic genotypes were $[29,30]$ or were not $[24,32,34,35]$ identified among privately owned dogs, while in other studies, potentially zoonotic genotypes appeared to be prevalent or showed a high prevalence among kennel or stray dogs [23,25], or were almost completely absent $[26,33]$. Moreover, this variability additionally emerged by the comparison of G. duodenalis geno- 
types in the different kennels here examined, as potentially zoonotic genotypes were identified in all of them, while canine genotypes were present in only two of them.

The reasons for the high variability of G. duodenalis genotypes found in kennels in previous studies and in this study may depend on numerous factors related to kennel management, genotypes infecting new entry dogs and the possibility that these genotypes may spread to other dogs.

Therefore, the findings from this study confirm data from other recent studies $[3,6,25]$ showing that the transmission of potentially zoonotic genotypes is not limited to household dogs but can also be high in dogs living in large communities, as in sheltered dogs, in which the presence of dog-specific genotypes was thought to be favoured and competing with the transmission of other genotypes $[1,2,5,28]$. The increased occurrence of zoonotic assemblages in dogs in recent years has been suggested to be the consequence of more frequent cross-species transmission of G. duodenalis between humans and dogs [5].

\section{Materials and Methods}

\subsection{Animals and Kennels}

From September 2018 to July 2019, a total of 168 dogs of different ages (2 months-17 years) were included in the study. Dogs lived in four different shelters from the Northern region of Tuscany (central Italy), namely, the kennels of Valdarno (65 dogs), Pistoia (48 dogs), Prato (33 dogs) and Florence (22 dogs).

For the control of parasites, in the examined kennels, all dogs are treated at the time of their entry and about once a year with a commercial anthelmintic drug containing febantel, pyrantel and praziquantel.

In all these shelters, dogs are single caged. Cleaning and disinfection are performed by using chlorine-based disinfectant solutions.

\subsection{Sampling}

Individual faecal samples were collected from all examined dogs. In all kennels, sampling was performed four times/year to include the four seasons: autumn (OctoberDecember 2018), winter (January-March 2019), spring (April-May 2019) and summer (June-July 2019). Each dog was sampled only once.

Collection of samples and manipulation of animals were authorised by the shelters and the Italian Ministry of Health in the framework of the Italian surveillance programs for potential zoonotic diseases (Italian law No. 281-1991).

\subsection{Parasitological and Immunological Analysis}

Faecal samples were examined using a commercial rapid immunoassay to detect Giardia spp. and Cryptosporidium spp. faecal antigens (RIDASCREEN ${ }^{\circledR}$ Cryptosporidium/Giardia Combi, R-Biopharm, Darmstadt, Germany). For the identification of helminthic eggs and cysts/oocysts of protozoa, all faecal samples were analysed microscopically by the Mini-FLOTAC technique [47].

\subsection{Molecular Analysis}

On a sub-group of Giardia-positive samples (25/69, 3-8/shelter), which included those samples from each kennel found strongly positive during the immunoassay, molecular analysis was performed to identify the species and genotypes of Giardia. For DNA extraction, samples were processed using a commercial kit (QIAamp DNA Stool Mini Kit, QIAGEN, Valencia, CA, USA). PCR protocols were applied to amplify fragments of the small subunit ribosomal RNA (SSU rRNA, $130 \mathrm{bp}$ ) [48], of $\beta$-giardin ( $\beta$-giardin, $384 \mathrm{bp}$ ) [49] and of the triose phosphate isomerase (tpi, $530 \mathrm{bp}$ ) [50] genes. Positive amplicons were purified using mi-PCR Purification Kit, Metabion International AG. Amplification products were sent to an external laboratory for sequencing (Bio-Fab Research, Rome, Italy). Forward and reverse sequences were manually checked using Finch TV 1.4 software (Geospiza, Inc., Seattle, 
WA, USA). The obtained consensus sequences were then compared with those available on GenBank database using the Standard Nucleotide BLAST search.

\subsection{Statistical Analysis}

Statistical analysis was performed with Stata ${ }^{\circledR}$ v12.0 (Stata Corp., College Station, TX, USA) and the significance level was set at $p<0.05$.

The chi square test was used to assess any statistical differences in the prevalence of G. duodenalis according to the age and kennel of provenance of dogs and sampling season. According to age, dogs were divided into four groups: $\leq 6$ months, $6-12$ months, $1-8$ years and $>8$ years.

Multivariate logistic regression analysis was used to evaluate potential statistical correlations between G. duodenalis and the selected independent variables (age, kennel of provenance and season).

\section{Conclusions}

The high prevalence of $G$. duodenalis and the identification of potentially zoonotic genotypes in all examined kennels underline the need to monitor sheltered dogs for this infection, to improve routine Giardia control measures in kennels and to provide insights into the zoonotic potential of G. duodenalis in sheltered dogs.

Author Contributions: Conceptualisation, S.P. and F.B.; methodology, A.A., S.P. and F.B.; validation, A.A., F.B., M.M., I.G.P., E.L., N.V., S.P.; formal analysis, N.V. and A.A.; investigation, all authors; resources, all authors; data curation, all authors; writing-original draft preparation, S.P., M.M. and F.B.; writing - review and editing, all authors; supervision, S.P. and F.B.; project administration, S.P. and F.B. All authors have read and agreed to the published version of the manuscript.

Funding: This research received no external funding.

Institutional Review Board Statement: Collection of samples and manipulation of animals were authorised by the kennels and the Italian Ministry of Health in the framework of the Italian surveillance programs for potential zoonotic diseases of stray animals (Italian law No. 281-1991).

Informed Consent Statement: Not applicable.

Data Availability Statement: Not applicable.

Conflicts of Interest: The authors declare no conflict of interest.

\section{References}

1. Ryan, U.; Cacciò, S.M. Zoonotic potential of Giardia. Int. J. Parasitol. 2013, 43, 943-956. [CrossRef]

2. Feng, Y.; Xiao, L. Zoonotic potential and molecular epidemiology of Giardia species and giardiasis. Clin. Microbiol. Rev. 2011, 24, 110-140. [CrossRef]

3. Einarsson, E.; Maayeh, S.; Svärd, S.G. An up-date on Giardia and giardiasis. Curr. Opin. Microbiol. 2016, 34, 47-52. [CrossRef] [PubMed]

4. Rosa, L.A.; Gomes, M.A.; Mundim, A.V.; Mundim, M.J.; Pozzer, E.L.; Faria, E.S.; Viana, J.C.; Cury, M.C. Infection of dogs by experimental inoculation with human isolates of Giardia duodenalis: Clinical and laboratory manifestations. Vet. Parasitol. 2007, 145, 37-44. [CrossRef] [PubMed]

5. Cai, W.; Ryan, U.; Xiao, L.; Feng, Y. Zoonotic giardiasis: An update. Parasitol. Res. 2021, 120, 4199-4218. [CrossRef] [PubMed]

6. Adell-Aledón, M.; Köster, P.C.; de Lucio, A.; Puente, P.; Hernández-de-Mingo, M.; Sánchez-Thevenet, P.; Dea-Ayuela, M.A.; Carmena, D. Occurrence and molecular epidemiology of Giardia duodenalis infection in dog populations in eastern Spain. BMC Vet. Res. 2018, 14, 26. [CrossRef] [PubMed]

7. Upjohn, M.; Cobb, C.; Monger, J.; Geurden, T.; Claerebout, E.; Fox, M. Prevalence, molecular typing and risk factor analysis for Giardia duodenalis infections in dogs in a central London rescue shelter. Vet. Parasitol. 2010, 172, 341-346. [CrossRef]

8. Uiterwijk, M.; Mughini-Gras, L.; Nijsse, R.; Wagenaar, J.A.; Ploeger, H.W.; Kooyman, F.N.J. Giardia duodenalis multi-locus genotypes in dogs with different levels of synanthropism and clinical signs. Parasit. Vectors 2020, 13, 605. [CrossRef]

9. Esch, K.J.; Petersen, C.A. Transmission and epidemiology of zoonotic protozoal diseases of companion animals. Clin. Microbiol. Rev. 2013, 1, 158-185. [CrossRef] 
10. Eligio-García, L.; Cortes-Campos, A.; Cota-Guajardo, S.; Gaxiola, S.; Jiménez-Cardoso, E. Frequency of Giardia intestinalis assemblages isolated from dogs and humans in a community from Culiacan, Sinaloa, Mexico using beta-giardin restriction gene. Vet. Parasitol. 2008, 156, 205-209. [CrossRef] [PubMed]

11. Ballweber, L.R.; Xiao, L.; Bowman, D.D.; Kahn, G.; Cama, V.A. Giardiasis in dogs and cats: Update on epidemiology and public health significance. Trends Parasitol. 2010, 26, 180-189. [CrossRef]

12. Traub, R.J.; Monis, P.T.; Robertson, I.; Irwin, P.; Mencke, N.; Thompson, R.C. Epidemiological and molecular evidence supports the zoonotic transmission of Giardia among humans and dogs living in the same community. Parasitology 2004, 128, $253-262$. [CrossRef]

13. Marangi, M.; Berrilli, F.; Otranto, D.; Giangaspero, A. Genotyping of Giardia duodenalis among children and dogs in a closed socially deprived community from Italy. Zoonoses Public Health 2010, 57, e54-e58. [CrossRef] [PubMed]

14. Kuthyar, S.; Kowalewski, M.M.; Seabolt, M.; Roellig, D.M.; Gillespie, T.R. Molecular characterization of Giardia duodenalis and evidence for cross-species transmission in Northern Argentina. Transbound. Emerg. Dis. 2021, 5, 1-10. [CrossRef] [PubMed]

15. Palmer, C.S.; Traub, R.J.; Robertson, I.D.; Devlin, G.; Rees, R.; Thompson, R.C. Determining the zoonotic significance of Giardia and Cryptosporidium in Australian dogs and cats. Vet. Parasitol. 2008, 154, 142-147. [CrossRef] [PubMed]

16. Tangtrongsup, S.; Scorza, V. Update on the Diagnosis and Management of Giardia spp. Infections in Dogs and Cats. Top. Companion Anim. Med. 2010, 25, 155-162. [CrossRef]

17. Bouzid, M.; Halai, K.; Jeffreys, D.; Hunter, P. The prevalence of Giardia infection in dogs and cats, a systematic review and meta-analysis of prevalence studies from stool samples. Vet. Parasitol. 2015, 207, 81-202. [CrossRef]

18. Villeneuve, V.; Beugnet, F.; Bourdoiseau, G. Efficacy of oxfendazole for the treatment of giardiosis in dogs. Experiments in dog breeding kennels. Parasite 2000, 7, 221-226. [CrossRef]

19. Gil, H.; Cano, L.; de Lucio, A.; Bailo, B.; de Mingo, M.H.; Cardona, G.A.; Fernández-Basterra, J.A.; Aramburu-Aguirre, J.; López-Molina, N.; Carmena, D. Detection and molecular diversity of Giardia duodenalis and Cryptosporidium spp. in sheltered dogs and cats in Northern Spain. Infect. Genet. Evol. 2017, 50, 62-69. [CrossRef]

20. Sommer, M.F.; Beck, R.; Ionita, M.; Stefanovska, J.; Vasić, A.; Zdravković, N.; Hamel, D.; Rehbein, S.; Knaus, M.; Mitrea, I.L.; et al. Multilocus sequence typing of canine Giardia duodenalis from South Eastern European countries. Parasitol. Res. 2015, 114 2165-2174. [CrossRef]

21. Capelli, G.; Frangipane di Regalbono, A.; Iorio, R.; Pietrobelli, M.; Paoletti, B.; Giangaspero, A. Giardia species and other intestinal parasites in dogs in north-east and central Italy. Vet. Rec. 2006, 159, 422-424. [CrossRef]

22. Paoletti, B.; Iorio, R.; Capelli, G.; Sparagano, O.A.; Giangaspero, A. Epidemiological scenario of giardiosis in dogs from central Italy. Ann. N. Y. Acad. Sci. 2008, 1149, 371-374. [CrossRef] [PubMed]

23. Scaramozzino, P.; Di Cave, D.; Berrilli, F.; D'Orazi, C.; Spaziani, A.; Mazzanti, S.; Scholl, F.; De Liberato, C. A study of the prevalence and genotypes of Giardia duodenalis infecting kennelled dogs. Vet. J. 2009, 182, 231-234. [CrossRef] [PubMed]

24. Paoletti, B.; Traversa, D.; Iorio, R.; De Berardinis, A.; Bartolini, R.; Salini, R.; Di Cesare, A. Zoonotic parasites in feces and fur of stray and private dogs from Italy. Parasitol. Res. 2015, 114, 2135-2141. [CrossRef] [PubMed]

25. Sauda, F.; Malandrucco, L.; Macrì, G.; Scarpulla, M.; De Liberato, C.; Terracciano, G.; Fichi, G.; Berrilli, F.; Perrucci, S. Leishmania infantum, Dirofilaria spp. and other endoparasite infections in kennel dogs in central Italy. Parasite 2018, 25, 2. [CrossRef] [PubMed]

26. Simonato, G.; Frangipane di Regalbono, A.; Cassini, R.; Traversa, D.; Beraldo, P.; Tessarin, C.; Pietrobelli, M. Copromicroscopic and molecular investigations on intestinal parasites in kenneled dogs. Parasitol. Res. 2015, 114, 1963-1970. [CrossRef]

27. Fantinatti, M.; Caseca, A.C.; Bello, A.R.; Fernandes, O.; Da-Cruz, A.M. The presence of Giardia lamblia assemblage A in dogs suggests an anthropozoonotic cycle of the parasite in Rio de Janeiro, Brazil. Infect. Genet. Evol. 2018, 65, 265-269. [CrossRef]

28. Covacin, C.; Aucoin, D.P.; Elliot, A.; Thompson, R.C. Genotypic characterisation of Giardia from domestic dogs in the USA. Vet. Parasitol. 2011, 177, 28-32. [CrossRef] [PubMed]

29. Lalle, M.; Pozio, E.; Capelli, G.; Bruschi, F.; Crotti, D.; Cacciò, S.M. Genetic heterogeneity at the beta-giardin locus among human and animal isolates of Giardia duodenalis and identification of potentially zoonotic subgenotypes. Int. J. Parasitol. 2005, 35, 207-213. [CrossRef]

30. Riggio, F.; Mannella, R.; Ariti, G.; Perrucci, S. Intestinal and lung parasites in owned dogs and cats from central Italy. Vet. Parasitol. 2013, 193, 78-84. [CrossRef] [PubMed]

31. Pipia, A.P.; Varcasia, A.; Tamponi, C.; Sanna, G.; Soda, M.; Paoletti, B.; Traversa, D.; Scala, A. Canine giardiosis in Sardinia Island, Italy: Prevalence, molecular characterization, and risk factors. J. Infect. Dev. Ctries. 2014, 8, 655-660. [CrossRef]

32. Zanzani, S.A.; Gazzonis, A.L.; Scarpa, P.; Berrilli, F.; Manfredi, M.T. Intestinal parasites of owned dogs and cats from metropolitan and micropolitan areas: Prevalence, zoonotic risks, and pet owner awareness in northern Italy. Biomed. Res. Int. 2014, 2014, 696508. [CrossRef]

33. De Liberato, C.; Berrilli, F.; Odorizi, L.; Scarcella, R.; Barni, M.; Amoruso, C.; Scarito, A.; Di Filippo, M.M.; Carvelli, A.; Iacoponi, F.; et al. Parasites in stray dogs from Italy: Prevalence, risk factors and management concerns. Acta Parasitol. 2018, 63, 27-32. [CrossRef]

34. Perrucci, S.; Berrilli, F.; Procopio, C.; Di Filippo, M.M.; Pierini, A.; Marchetti, V. Giardia duodenalis infection in dogs affected by primary chronic enteropathy. Open Vet. J. 2020, 10, 74-79. [CrossRef] 
35. Ciuca, L.; Pepe, P.; Bosco, A.; Cacciò, S.M.; Maurelli, M.P.; Sannella, A.R.; Vismarra, A.; Cringoli, G.; Kramer, L.; Rinaldi, L.; et al. Effectiveness of Fenbendazole and Metronidazole Against Giardia Infection in Dogs Monitored for 50-Days in Home-Conditions. Front. Vet. Sci. 2021, 8, 626424. [CrossRef]

36. Huber, F.; Bomfim, T.C.; Gomes, R.S. Comparison between natural infection by Cryptosporidium sp., Giardia sp. in dogs in two living situations in the West Zone of the municipality of Rio de Janeiro. Vet. Parasitol. 2005, 130, 69-72. [CrossRef] [PubMed]

37. Liu, J.; Lee, S.E.; Song, K.H. Prevalence of canine giardiosis in South Korea. Res. Vet. Sci. 2008, 84, 416-418. [CrossRef] [PubMed]

38. Capelli, G.; Paoletti, B.; Iorio, R.; Frangipane Di Regalbono, A.; Pietrobelli, M.; Bianciardi, P.; Giangaspero, A. Prevalence of Giardia spp. in dogs and humans in northern and central Italy. Parasitol. Res. 2003, 90 (Suppl. 3), S154-S155. [CrossRef]

39. Gates, M.C.; Nolan, T.J. Endoparasite prevalence and recurrence across different age groups of dogs and cats. Vet. Parasitol. 2009, 166, 153-158. [CrossRef]

40. Bianciardi, P.; Papini, R.; Cardini, G. Prevalence of Giardia antigen in stool samples from dogs and cats. Rev. Med. Vet. 2004, 155, 417-421.

41. Salant, H.; Kuzi, S.; Navarro, D.; Baneth, G. Prevalence and molecular characterization of Giardia duodenalis in dogs in Israel. Comp. Immunol. Microbiol. Infect. Dis. 2020, 73, 101548. [CrossRef] [PubMed]

42. Fontanarrosa, M.F.; Vezzani, D.; Basabe, J.; Eiras, D.F. An epidemiological study of gastrointestinal parasites of dogs from Southern Greater Buenos Aires (Argentina): Age, gender, breed, mixed infections, and seasonal and spatial patterns. Vet. Parasitol. 2006, 136, 283-295. [CrossRef]

43. Bowman, D.D.; Montgomery, S.P.; Zajac, A.M.; Eberhard, M.L.; Kazacos, K.R. Hookworms of dogs and cats as agents of cutaneous larva migrans. Trends Parasitol. 2010, 26, 162-167. [CrossRef]

44. Fiechter, R.; Deplazes, P.; Schnyder, M. Control of Giardia infections with ronidazole and intensive hygiene management in a dog kennel. Vet. Parasitol. 2012, 187, 93-98. [CrossRef] [PubMed]

45. Šoba, B.; Islamović, S.; Skvarč, M.; Cacciò, S.M. Multilocus genotyping of Giardia duodenalis (Lambl, 1859) from symptomatic human infections in Slovenia. Folia Parasitol. 2015, 62, 10-14411. [CrossRef]

46. Berrilli, F.; Di Cave, D.; De Liberato, C.; Franco, A.; Scaramozzino, P.; Orecchia, P. Genotype characterisation of Giardia duodenalis isolates from domestic and farm animals by SSU-rRNA gene sequencing. Vet. Parasitol. 2004, 122, 193-199. [CrossRef] [PubMed]

47. Cringoli, G.; Maurelli, M.P.; Levecke, B.; Bosco, A.; Vercruysse, J.; Utzinger, J.; Utzinger, J.; Rinaldi, L. The Mini-FLOTAC technique for the diagnosis of helminth and protozoan infections in humans and animals. Nat. Protoc. 2017, 12, 1723-1732. [CrossRef]

48. Read, C.; Walters, J.; Robertson, I.D.; Thompson, R.C.A. Correlation between genotype of Giardia duodenalis and diarrhoea. Int. J. Parasitol. 2002, 32, 229-231. [CrossRef]

49. Cacciò, S.M.; De Giacomo, M.; Pozio, E. Sequence analysis of the $\beta$-giardin gene and development of a polymerase chain reac-tion-restriction fragment length polymorphism assay to genotype Giardia duodenalis cysts from human faecal samples. Int. J. Parasitol. 2002, 32, 1023-1030. [CrossRef]

50. Sulaiman, I.M.; Fayer, R.; Bern, C.; Gilman, R.H.; Trout, J.M.; Schantz, P.M.; Das, P.; Lal, A.A.; Xiao, L. Triosephosphate isomerase gene characterization and potential zoonotic transmission of Giardia duodenalis. Emerg. Infect. Dis. 2003, 9, 1444-1452. [CrossRef] 